\title{
Fix seniors' care first, says CMA president-elect
}

I t's time the federal government takes a bigger role in transforming health care to meet the needs of aging Canadians, says the incoming president of the Canadian Medical Association (CMA) on the cusp of the Aug. 18-20 annual meeting.

"For too long, they've fallen back on the constitutional framework that health care is a provincial responsibility," says CMA president-elect Dr. Chris Simpson. "If you look across the Atlantic to more successful health systems, what they have in common is ambitious goals, engaged doctors and strong national governments willing to lead the change."

Simpson is slated to take the helm of the CMA on Aug. 20 during the organization's annual general meeting in Ottawa. Currently, he is professor of medicine and chief of cardiology at Queen's University in Kingston, Ontario, as well as medical director of the cardiac program at Kingston General Hospital/ Hotel Dieu Hospital.

As chair of both the Wait Time Alliance and the Canadian Cardiovascular Society's health policy and advocacy committee, Simpson has championed better access to care. He attributes Canada's recent poor performance on wait times and other health indicators to "the fact that our health care system hasn't changed to meet the ways society has changed."

Simpson joined CMAJ by phone to share his views on wait times, private health care, euthanasia, medical marijuana and his goals for the year ahead.

CMAJ: What's on the agenda for your coming term as CMA president?

Simpson: We'll be challenging the federal parties to tell Canadians their vision for seniors care. ... How are we going to dehospitalize our health care system and specifically, why shouldn't [the federal government] be part of the solution?

CMAJ: Where is change most needed to serve seniors better?

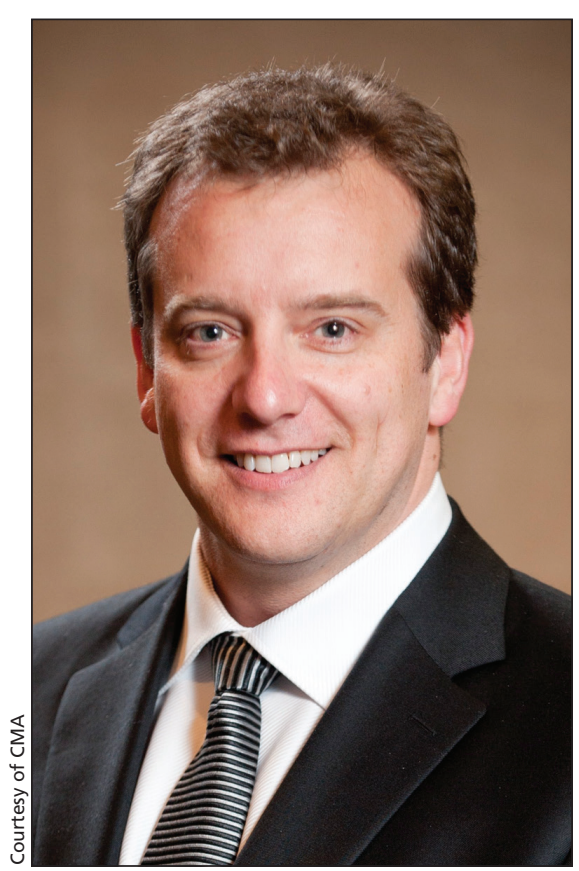

Improving care for all Canadians starts with ensuring seniors receive the right care in the right place, says Canadian Medical Association president-elect Dr. Chris Simpson.

Simpson: These patients are being shoehorned into the hospital system, which isn't designed for them. They're not getting the care they need, and at the same time they're preventing other patients from getting the acute care hospitals are supposed to provide. That's why our wait times are long, our emergency departments are crowded, and we have infections and other bad things happening in hospitals - people are there too long for the wrong reasons.

CMAJ: Former CMA president Dr. Brian Day will argue before British Columbia's top court in September that restricting access to private health care in the face of long waits violates patients' rights. What's your take on the challenge?

Simpson: Suggesting that providing more payment options or routes to therapy via the private sector is a bit of a red herring and isn't what's wrong with wait times in Canada, nor will it fix wait times in Canada. [Top internationally ranked health systems] haven't done it by increasing private spending; they've done it through fundamental structural changes.

CMAJ: Many people expect Day's challenge will head to the Supreme Court of Canada. If that happens, will the CMA apply to intervene?

Simpson: That's certainly a discussion we'd have at the [CMA Board of Directors], and the organization would always stand by our health care transformation agenda. We'd be making the point that structural changes are needed - that's really the way forward - and our history has been to provide information and clarity and expertise wherever we can. I'm certain we'd have something to say, but I wouldn't preclude the board's views on that.

CMAJ: Debate over euthanasia and physician-assisted dying continues to dominate discussions about end-of-life care. Where do you see things heading on that issue?

Simpson: The discussion at [CMA] general council last year very quickly degenerated into debates about terminology and we took a hit in the press with people like André Picard [of The Globe and Mail] accusing us of ducking the issue. ... I didn't anticipate there would be so much positive action to come out of that legitimate criticism. The CMA moved to clarify terminology. We had town halls across the country to consult Canadians. We've done more than any of the political parties to advance the discussion in a helpful way ... and I think it's going to set us up to have more meaningful discussion at this year's general council and help us prepare for the potential legal changes.

CMAJ: What did you take away from watching the town hall discussions unfold?

Simpson: Physicians are divided on the issue, just as Canadians are divided 
on the issue. My personal observation is that the discussion has been extremely respectful, more informed and less rhetorical than it has been in the past, and I think that's healthy.

CMAJ: Canada's changing medical marijuana landscape has stirred controversy and confusion in the past year, with outgoing CMA president Dr. Louis Hugo Francescutti vocally opposing the new regime. Where do you stand on the issue?

Simpson: Trying to tone down the rhetoric. If there is a therapeutic use for cannabis, we're very interested in knowing what that is, but we must insist it be done in a way that protects our patients from inadvertent harm and allows us to prescribe in an environment of certainty or greater certainty than we have now.

CMAJ: You're pretty savvy on social media; do you have any plans for physician engagement through new media?

Simpson: It's a great way to let people know what and how I think. I've used it to introduce myself to people, and as a way to get feedback on issues that are important to me. I know it's not going to be for every physician, but for leaders and those looking to influence and be influenced by opinion, it's a wonderful tool.

CMAJ: Will you keep up your current positions in Kingston in the year ahead?

Simpson: I'm anticipating I'll be able to manage things reasonably well. I'll be scaling back my clinical work to one day a week on average, and I have a lot of great colleagues who are going to fill the gaps for me. — Lauren Vogel, CMAJ

CMAJ 2014. DOI:10.1503/cmaj.109-4875 